CZASOPISMO INŻYNIERII LĄDOWEJ, ŚRODOWISKA I ARCHITEKTURY JOURNAL OF CIVIL ENGINEERING, ENVIRONMENT AND ARCHITECTURE

JCEEA, t. XXXIII, z. 63 (4/16), październik-grudzień 2016, s. 523-529

\author{
Andrzej STUDZIŃSKI ${ }^{1}$
}

\title{
OCENA KOSZTÓW ZAKŁADÓW WODOCIĄGOWYCH
}

\begin{abstract}
W pracy przedstawiono ocenę kosztów eksploatacyjnych dwóch zakładów wodociągowych: stacji uzdatniania wody A o wydajności $17000 \mathrm{~m}^{3} / \mathrm{d}$ oraz przedsiębiorstwa wodociagoowego B eksploatującego system zaopatrzenia w wodę o wydajności $5760 \mathrm{~m}^{3} / \mathrm{d}$. Zakłady te łączy zakończona w 2014 roku modernizacja i w przypadku drugiego z nich rozbudowa, są to nowoczesne zakłady w pełni spełniające stawiane przed nimi zadania. Przedstawiono koszty eksploatacyjne w 2015 roku zestawione $\mathrm{w}$ układzie rodzajowym, podstawą opracowania są dane pochodzące $\mathrm{z}$ tych przedsiębiorstw. W strukturze kosztów można zauważyć dwie wspólne cechy - znaczący, ponad $40 \%$ udział amortyzacji w kosztach ogólnych oraz koszty płac wraz z narzutami, które stanowiły ponad $20 \%$ wydatków. Pozostałe grupy kosztów: materiały, energia, opłaty i podatki, usługi obce i pozostałe koszty stanowiły znikomy udział w kosztach ogólnych. Konsekwencją modernizacji były wysokie koszty jednostkowe produkcji wody, wynoszące w zakładzie A $2,25 \mathrm{zł} / \mathrm{m}^{3}$, z których $0,92 \mathrm{zz} / \mathrm{m}^{3}$ stanowiła amortyzacja. Zaledwie $0,40 \mathrm{zł} / \mathrm{m}^{3}$ wyniosły koszty zmienne. W zakładzie $\mathrm{B}$ koszty jednostkowe określono na $5,42 \mathrm{zt} / \mathrm{m}^{3}$, w których $2,62 \mathrm{zt} / \mathrm{m}^{3}$ to amortyzacja natomiast $1,14 \mathrm{zz} / \mathrm{m}^{3}$ to koszty zmienne. Porównując otrzymane wielkości $\mathrm{z}$ danymi literaturowymi można stwierdzić, że koszty w badanych zakładach znacznie przewyższają dane literaturowe dla zakładów o zbliżonej wydajności. Wynika to w dużej mierze z kosztów amortyzacji, które są konsekwencją prowadzonych kosztownych działań modernizacyjnych.
\end{abstract}

Słowa kluczowe: stacja uzdatniania wody, wodociąg, koszty eksploatacyjne, układ rodzajowy

\section{Wprowadzenie}

Koszty, jakie ponosi przedsiębiorstwo wodociągowe, są jednym z podstawowych czynników, które decydują o wysokości taryfy za usługi wodociągowe. Określają one wysokość wydatków poniesionych na prawidłowe przeprowadzenie działalności usługowej [1]. Przedsiębiorstwa wodociągów mogą posługiwać się różnymi sposobami grupowania oraz klasyfikacji kosztów własnych [2]. Wy-

\footnotetext{
${ }^{1}$ Andrzej Studziński, Politechnika Rzeszowska, Zakład Zaopatrzenia w Wodę i Odprowadzania Ścieków, Al. Powstańców Warszawy 6, 35-959 Rzeszów; tel. 178651703; astud@prz.edu.pl
} 
różnia się trzy podstawowe układy takiej klasyfikacji: układ rodzajowy, układ stanowiskowo-kalkulacyjny, układ ekonomiczny [1].

Układ rodzajowy przedstawia koszty własne w takiej postaci, w jakiej rzeczywiście ponoszą je przedsiębiorstwa wodociągowe. Podstawowym celem tej klasyfikacji jest identyfikacja struktury kosztów. Przykładowy układ rodzajowy może przedstawiać się następująco:

- koszty materialne:

- energia,

- amortyzacja,

- zużycie materiałów oraz środków nietrwałych,

- usługi remontowe,

- usługi transportowe,

-inne usługi);

- koszty niematerialne:

- wynagrodzenia pracowników,

- odpisy na fundusze,

- narzuty na prace,

- usługi bankowe,

- podatki;

- inne usługi niematerialne.

Układ ekonomiczny dzieli koszty w zależności od reakcji na zmiany wielkości świadczonych usług. Z tego względu koszty dzieli się na stałe lub zmienne. Koszty zmienne i stałe na ogół rzadko występują w czystej postaci, dlatego przy tworzeniu ekonomicznego układu kosztów wprowadza się często pojęcia kosztów umownie stałych oraz kosztów umownie zmiennych [3].

Celem niniejszego opracowania jest ekonomiczna analiza kosztów przykładowego zakładu uzdatniania wody oraz przykładowego systemu zaopatrzenia w wodę. Przedstawiono strukturę kosztów zakładów w układach rodzajowym oraz ekonomicznym. Podstawą opracowania są dane dotyczące jakości wody surowej i uzdatnionej, wydajności, zużycia energii oraz kosztów poniesionych przez wyżej wymienione zakładu w 2015 roku. Rozpatrywane zakłady łączy modernizacja przeprowadzona w ostatnich latach i zakończona w 2014 roku, są to zakłady nowoczesne technologicznie, działające w pełni automatycznie. Konsekwencją takiego stanu jest wysoki udział amortyzacji w kosztach eksploatacji tych zakładów.

\section{Koszty eksploatacyjne zakładu uzdatniania wody A}

\subsection{Opis zakładu uzdatniania wody $\mathrm{A}$}

Zakład A jest zakładem o zdolności produkcyjnej 17000 m³/d, został oddany do użytku (po gruntownej modernizacji) na początku 2014 roku. Wykorzystuje jako wodę surową wody powierzchniowe zaliczające się do kategorii A1 
[4]. Technologia uzdatniania obejmuje następujące procesy jednostkowe: utlenianie wstępne, koagulacja, sedymentacja, filtracja i dezynfekcja, alternatywnie proces można wspomagać stosując sorpcję. Proces uzdatniania trwa do $12 \mathrm{~h}$. Woda uzdatniona gromadzona jest $\mathrm{w}$ zbiornikach a następnie wtłaczana do sieci wodociągowej. Analizowane koszty dotyczą układu od ujęcia do pompowni $2^{\circ}$ włącznie. W analizowanym okresie woda dostarczana do sieci wodociągowej spełniała wymogi stawiane jakości wody do spożycia [5].

\subsection{Koszty eksploatacyjne zakładu uzdatniania wody A}

Rejestr kosztów poniesionych przez zakład uzdatniania wody A w 2015 roku został zestawiony w układzie rodzajowym, przedstawiono go w tabeli 1 .

Tabela 1. Koszty poniesione przez zakład A w 2015 r.

Table 1. Costs incurred by the plant A in 2015

\begin{tabular}{|l|r|}
\hline \multicolumn{1}{|c|}{ Rodzaj kosztu } & Kosz roczny 2015 [zł] \\
\hline Amortyzacja & 1746803 \\
\hline Wynagrodzenia z narzutami & 721898 \\
\hline Materiały & 172415 \\
\hline Energia & 310734 \\
\hline Opłata za korzystanie ze środowiska & 111181 \\
\hline Podatki i opłaty - inne & 412647 \\
\hline Usługi obce & 200992 \\
\hline Pozostałe koszty & 578524 \\
\hline Razem & 4255194 \\
\hline
\end{tabular}

Rejestr kosztów poniesionych Na podstawie tabeli 1 można zauważyć, że największym udziałem w kosztach zakładu uzdatniania wody A była amortyzacja, która wyniosła 41,05\%. Drugą istotną pozycją były koszty ogólnozakładowe i wydziałowe stanowiące $24,64 \%$. Znaczącą pozycję zajęły również płace wraz z narzutami wynoszące $16,59 \%$. Zestawiając otrzymane dane w ekonomiczny układ klasyfikacji kosztów możemy zauważyć, że koszty stałe to aż 3508243 zł, co stanowiło 82,45\% wartości kosztów całościowych. Koszty zmienne - materiały, energia i opłaty wyniosły 746951 zł i stanowiły 17,55\% kosztów ogólnych.

W celu określenia jednostkowego kosztu eksploatacji stacji uzdatniania wody zastosowano następującą zależność [6, 7]:

$$
k=\frac{K}{Q_{r}}
$$

gdzie: $k$-jednostkowy koszt eksploatacji stacji uzdatniania wody $\left[\mathrm{z} \mathrm{k} / \mathrm{m}^{3}\right]$;

$K$-roczny koszt eksploatacji stacji uzdatniania wody [zł/rok];

$Q_{r}$-roczna wydajność stacji uzdatniania wody próbki [m³/rok]. 
Jak wynika z powyższej zależności jednostkowy koszt eksploatacji stacji uzdatniania wody wynosił $2,25 \mathrm{zz} / \mathrm{m}^{3}$. Analogicznie określono jednostkowy koszt stały, wynoszący $1,85 \mathrm{zł} / \mathrm{m}^{3}$, oraz jednostkowy koszt zmienny, którego wartość oszacowano na $0,40 \mathrm{z} / \mathrm{m}^{3}$. Na podstawie otrzymanych wyników można zauważyć, jak dużą część kosztów ujęcia, uzdatnienia i przesłania wody do sieci stanowią koszty stałe. Wśród kosztów stałych największą jednostkową kwotą odznacza się amortyzacja, która wyniosła $0,92 \mathrm{zł} / \mathrm{m}^{3}$, co stanowiło niemal połowę jednostkowego kosztu stałego. Najmniejszą kwotą wśród tej grupy kosztów charakteryzowały się remonty wynoszące jedynie $0,01 \mathrm{z} z / \mathrm{m}^{3}$. Koszty ogólnozakładowe i wydziałowe stanowiły $0,55 \mathrm{zł} / \mathrm{m}^{3}$, z kolei płace wraz z narzutami to kwota wynosząca $0,37 \mathrm{zt} / \mathrm{m}^{3}$, co stanowiło $1 / 5$ jednostkowego kosztu stałego. Struktura kosztów zmiennych przedstawia się następująco: materiały $0,09 \mathrm{zz} / \mathrm{m}^{3}$, energia elektryczna $-0,17 \mathrm{z} \mathrm{z} / \mathrm{m}^{3}$, opłaty $-0,14 \mathrm{zt} / \mathrm{m}^{3}$. Analizując dane dla poszczególnych miesięcy nie zauważono wyraźnej zależności pomiędzy zużyciem energii elektrycznej a objętością wyprodukowanej wody. Nie odnotowano również zależności pomiędzy jakością produkowanej wody a zużyciem energii, co wynikało głównie z wysokiej jakości wody surowej.

Porównując jednostkowy koszt eksploatacji stacji A z innymi stacjami uzdatniania wody opisywanymi w literaturze technicznej [2, 7, 8, 9], dla których koszty jednostkowe uzdatniania wody zaktualizowane do poziomu cen na koniec 2015 roku wynoszą od 0,16 do $1,25 \mathrm{z} ł / \mathrm{m}^{3}$, można stwierdzić, że jego wartość znacznie przewyższała koszty poniesione przez inne stacje zarówno o podobnych wydajnościach jak i dużo niższych.

\section{Koszty eksploatacyjne zakładu zaopatrzenia w wodę B}

\subsection{Opis zakładu B}

Zakład wodociągowy B jest wodociągiem gminnym zaopatrującym w wodę miejscowości na terenie 5-ciu sąsiadujących gmin. Wykorzystuje wody powierzchniowe o kategorii A3 [4], stacja uzdatniania wody posiada przepustowość $5760 \mathrm{~m}^{3} / \mathrm{d}$, ciąg technologiczny zawiera koagulację, sedymentację i filtrację oraz ozonowanie i sorpcję na węglu aktywnym, końcowym procesem jest dezynfekcja, procesy te pozwalały na uzyskanie jakości wody zgodnej z wymaganiami [5]. Długość sieci wodociągowej, będącej własnością przedsiębiorstwa, wyniosła na koniec 2015 r. łącznie 256,7 km, sieć wodociągowa współpracowała z 8 zbiornikami sieciowymi oraz 21 przepompowniami. W 2015 roku zakład wtłoczył do sieci wodociągowej $549960 \mathrm{~m}^{3}$ wody uzdatnionej.

\subsection{Koszty eksploatacyjne zakładu uzdatniania wody A}

Koszty w układzie rodzajowym przedstawiono w tabeli 2. Zastosowano układ tożsamy z przedstawionym powyżej dla zakładu A. 
Tabela 2. Koszty poniesione przez zakład B w 2015 r.

Table 2. Costs incurred by the plant B in 2015

\begin{tabular}{|l|r|}
\hline \multicolumn{1}{|c|}{ Rodzaj kosztu } & Kosz roczny 2015 [zł] \\
\hline Amortyzacja & 1438220 \\
\hline Wynagrodzenia z narzutami & 782457 \\
\hline Materiały & 186888 \\
\hline Energia & 417626 \\
\hline Opłata za korzystanie ze środowiska & 22799 \\
\hline Podatki i opłaty - inne & 8887 \\
\hline Usługi obce & 106731 \\
\hline Pozostałe koszty & 17147 \\
\hline Razem & 2980755 \\
\hline
\end{tabular}

W strukturze kosztów dominowały: amortyzacja, wynagrodzenia wraz z narzutami oraz koszt energii elektrycznej, łącznie w 2015 roku grupy te stanowiły od 85,53\% wszystkich kosztów.

Amortyzacja oraz odpisy umorzeń stanowiła 48,25\%, co wynikało z oddania do użytkowania nowych środków trwałych wytworzonych w trakcie modernizacji i rozbudowy systemu zaopatrzenia w wodę. Kolejną grupę stanowią wynagrodzenia wraz z narzutami $-26,25 \%$.

Wszystkie pozostałe grupy kosztów nie przekraczały $10 \%$, kolejną wartością były materiały $-6,27 \%$, kolejno koszty przedstawiały się następująco usługi obce $-3,58 \%$, opłaty za korzystanie ze środowiska $-0,76 \%$, podatki i opłaty $0,30 \%$ i pozostałe koszty $0,58 \%$.

Na podstawie danych tabeli 2 obliczono koszty jednostkowe odnoszące się do $1 \mathrm{~m}^{3}$ wody wtłoczonej do sieci wodociągowej. Koszt jednostkowy wody w zakładzie B wynosił aż $5,42 \mathrm{zł} / \mathrm{m}^{3}$. Najistotniejszym składnikiem kosztów całkowitych była amortyzacja, która wyniosła $2,62 \mathrm{zł} / \mathrm{m}^{3}$. Przyjmując, że na koszty zmienne przedstawione w tabeli 2 składają się kwoty z tytułu materiałów, energii elektrycznej i opłat środowiskowych, koszty te można określić kwotą $1,14 \mathrm{zt} / \mathrm{m}^{3}$.

\section{Podsumowanie}

Koszt eksploatacji zakładu A wyniósł 4255 194,38 zł. Jednostkowy koszt pracy zakładu wyniósł $2,25 \mathrm{zz} / \mathrm{m}^{3}$ wyprodukowanej wody, z czego $1,85 \mathrm{zz} / \mathrm{m}^{3}$ (82,54\% kosztu jednostkowego) stanowiło koszt stały, a $0,40 \mathrm{zz} / \mathrm{m}^{3}$ koszt zmienny. Największe znaczenie w kosztach stałych odegrała amortyzacja, której wartość wynosiła $0,92 \mathrm{zz} / \mathrm{m}^{3}$, natomiast najmniejszą kwotą charakteryzowały się remonty. Wśród kosztów zmiennych największy koszt jednostkowy stanowiła energia elektryczna wynosząca $0,17 \mathrm{zt} / \mathrm{m}^{3}$, a najmniejszy koszt zużycia materiałów stanowiący $0,09 \mathrm{zł} / \mathrm{m}^{3}$. 
Porównując jednostkowy koszt eksploatacji zakładu A z innymi stacjami wg danych literaturowych, można stwierdzić, że jego wartość znacznie przewyższa koszty poniesione przez inne stacje zarówno o podobnych wydajnościach jak i dużo niższych. Porównując wartości z zakładami o podobnej wydajności [7] koszt jednostkowy był prawie pięciokrotnie wyższy. Tak duże różnice jednostkowych kosztów mogą być spowodowane odmiennym sposobem uzdatniania wody, czy inną technologią zakładu. Bardzo istotnym składnikiem kosztów bieżących zakładu A była amortyzacja, która wyniosła aż 41\% kosztów.

Koszt jednostkowy produkcji wody w zakładzie wodociągowym B wynosił $5,42 \mathrm{zz} / \mathrm{m}^{3}$ w 2015 roku, na który składała się amortyzacja w kwocie 2,62 zt $/ \mathrm{m}^{3}$.

Porównując przedstawione zakłady można zauważyć, że głównym składnikiem kosztów jednostkowych była amortyzacja - w obu przypadkach przekraczająca $40 \%$ kosztów ogólnych. Było to wynikiem prac modernizacyjnych i rozbudowy omawianych zakładów. Drugim co do wielkości składnikiem kosztów są wynagrodzenia wraz z narzutami. W obu przypadkach grupy te stanowią ponad połowę kosztów produkcji wody.

W pozostałych grupach kosztów trudno dopatrywać się analogii, co wynika z różnej wielkości, funkcji i struktury omawianych zakładów.

Podsumowując można stwierdzić, że w krajowej literaturze naukowo technicznej niewiele jest danych dotyczących kosztów jednostkowych zakładów zaopatrzenia w wodę, przedstawione wielkości są ich uzupełnieniem. Celowe wydaje się kontynuowanie badań w tym zakresie, celem poszerzenia katalogu danych, które znajdują swoje zastosowanie nie tylko w przypadku ustalania opłat za wodę ale maja swoje przełożenie również $\mathrm{w}$ analizach ryzyka w eksploatacji sieci wodociągowej [10].

\section{Literatura}

[1] Kłoss-Trębaczkiewicz H., Osuch-Pajdzińska E.: Ekonomika przedsiębiorstwa komunalnego, Oficyna Wydawnicza Politechniki Warszawskiej, Warszawa 2015.

[2] Rauba E., Miłaszewski R.: Koszty funkcjonowania systemów zaopatrzenia w wodę, Zaopatrzenie w wodę, jakość i ochrona wód, Poznań 2012, s.137-163.

[3] Dziembowski Z.: Ekonomika przedsiębiorstwa komunalnego, PWN, Warszawa 1983.

[4] Rozporządzenie Ministra Zdrowia z dnia 29 marca 2007 r. w sprawie jakości wody przeznaczonej do spożycia przez ludzi (Dz.U. 2007 Nr 61, poz. 417 z późniejszymi zmianami).

[5] Rozporządzenie Ministra Środowiska z dnia 27 listopada 2002 r. w sprawie wymagań, jakim powinny odpowiadać wody powierzchniowe wykorzystywane do zaopatrzenia ludności w wodę przeznaczoną do spożycia (Dz. U. 2002 Nr 204, poz. 1728).

[6] Kuś K., Rożałowska R.: Wpływ kosztów produkcji i dystrybucji wody na cenę jej sprzedaży dla miast zaopatrywanych przez wodociąg grupowy GPW Katowice, Ochrona Środowiska, Nr 1, 2004, s. 13-16.

[7] Miłaszewski R.: Analiza kosztów stacji uzdatniania wód podziemnych i powierzchniowych, Instal 7-8/2015, s. 74-76. 
[8] Kisło A., Miłaszewski R., Skoczko I: Analiza kosztów eksploatacji miejskiej stacji uzdatniania wody w Suwałkach, Zaopatrzenie w wodę, jakość i ochrona wód, Poznań 2014, s. 137-163.

[9] Skoczko I., Miłaszeski R., Kisło A., Zadrożna S.: Zależność kosztów eksploatacji stacji uzdatniania wody podziemnej w Suwałkach od jej wydajności, Ekonomia i Środowisko, 3(54), 2015, s. 137-144.

[10] Studziński A., Pietrucha-Urbanik K. Preventive maintenance and reliability of water supply system elements. Czasopismo Inżynierii Lądowej, Środowiska i Architektury Journal of Civil Engineering, Environment And Architecture. JCEEA, z. 62 (3/I/2015), pp. 429-436. DOI: 10.7862/rb.2015.126.

\section{ASSESSMENT OF THE WATERWORKS OPERATING COSTS}

\section{S u m m a r y}

The paper presents an assessment of the operating costs of two water supply companies: water treatment plant A with a capacity of $17000 \mathrm{~m}^{3} / \mathrm{d}$, and the water supply company B, an operator of the water supply system with a capacity of $5760 \mathrm{~m}^{3} / \mathrm{d}$. These plants similarity is the modernization completed in 2014 and of the latter one extension, these are sophisticated facilities fully meet the tasks placed before them. The operating costs in 2015 were presented, shown by costs generic system. The basis for the development are the data from these companies. Two things in common can be noticed in the structure of the operating costs - significantly more than $40 \%$ share of depreciation in total costs and labor costs, which accounted for over $20 \%$ of the total costs. Other groups of costs: materials, energy, fees and taxes, outsourced services and other costs accounted for a small proportion of total costs. The consequence of modernization were high unit costs of production of water, amounting to plant A $2.25 \mathrm{zl} / \mathrm{m}^{3}$, of which $0.92 \mathrm{zl} / \mathrm{m}^{3}$ was depreciation. Only $0.40 \mathrm{zl} / \mathrm{m}^{3}$ were variable costs. The plant $\mathrm{B}$ unit costs were set at $5.42 \mathrm{zl} / \mathrm{m}^{3}$, in which $2.62 \mathrm{zl} / \mathrm{m}^{3}$ was depreciation and $1.14 \mathrm{zl} / \mathrm{m}^{3}$ variable costs. Comparing the operating costs in plant A to another water treatment plants, they are significantly higher. This is due to the depreciation costs, which were a consequence of the modernization.

Keywords: water treatment plant, water works, maintenance costs, generic system

DOI:10.7862/rb.2016.296

Przestano do redakcji: 9.09.2016 $r$.

Przyjęto do druku: 20.12.2016 r. 
